\title{
Antioxidative mechanism of Quercus infectoria gall aqueous extract against Candida albicans
}

\author{
Mohamad Zahid Kasiram, Asma Abdullah Nurul and Wan Abdul Wahab Wan-Nor-Amilah* \\ School of Health Sciences, Health Campus, Universiti Sains Malaysia, 16150 Kubang Kerian, Kelantan, Malaysia. \\ Email: dramilah@usm.my
}

Received 20 September 2020; Received in revised form 14 December 2020; Accepted 2 March 2021

\begin{abstract}
Aims: The effect of Quercus infectoria (QI) gall extract on the fungal expression of antioxidant defense enzymes of Candida albicans was studied in an effort to unravel its anti-fungal mechanism.

Methodology and results: Minimum inhibitory concentration (MIC), minimum fungicidal concentration (MFC), and time kill assays were conducted to analyse the antifungal activity of the extract against $C$. albicans. Total protein profiles of $C$. albicans were determined by SDS-PAGE and real-time PCR was used to quantify the genes expression level of superoxide dismutase (SOD1), catalase (CAT1) and glutathione peroxidase (GPX3) following treatment with aqueous QI gall extract. The MIC and MFC values of the extract against $C$. albicans were $8 \mathrm{mg} / \mathrm{mL}$ and $16 \mathrm{mg} / \mathrm{mL}$ respectively. Fungistatic and fungicidal activities of the extract were observed after $24 \mathrm{~h}$ at $1 \times \mathrm{MIC}$ and $2 \times \mathrm{MIC}$ from the time-kill assay. A lower total protein bands density of extract-treated $C$. albicans was visualized when compared to the untreated cells at concentrations of $1 \times$ MIC and $2 \times$ MIC. A significant reduction in the expression of GPX3 $(p<0.05)$ was observed following $2 \mathrm{~h}$ treatment of extract at $1 \times$ MIC and $2 \times$ MIC though it did not significantly affect those of SOD1 and CAT1 ( $p$ $>0.05$ ).

Conclusion, significance and impact of study: In conclusion, QI gall extract exerted an anti-Candida activity and it is apparently effective in downregulating the gene expression of GPX3 in C. albicans. Of note, the present findings elucidated a preliminary mechanism associated with the organism's survival resilience which represents a key target for the development of anti-Candida agents in future.
\end{abstract}

Keywords: Candida albicans, Quercus infectoria, glutathione peroxidase, superoxide dismutase, catalase

\section{INTRODUCTION}

Candida albicans is one of the pathogenic yeasts that has the ability to cause various types of diseases in a human. It is a predominant causative agent of candidiasis compared to other Candida species (Hawkshead et al., 2016) in which over $80 \%$ candidiasis were caused by $C$. albicans (Silva et al., 2012). The clinical spectrum of candidiasis is largely ranging from superficial to invasive infections (Sardi et al., 2013). Oral thrush, vulvovaginal candidiasis and urinary tract infection are some of the most common diseases caused by $C$. albicans in human (Dantas et al., 2015). Besides, it is also associated with invasive infections such as endocarditis and meningitis which are frequently related to high morbidity and mortality. High frequency of candidiasis has created a serious clinical problem worldwide and the infection rate keeps on increasing (Chin et al., 2016). In Malaysia, candidiasis represents about $64.1 \%$ among all other fungal infections (Tzar et al., 2013).
Human innate immune system has a sophisticated mechanism to recognize and kill the invading pathogen through an oxidative stress killing mechanism by which neutrophils and macrophages produce reactive oxygen species (ROS) (Weiss et al., 1985). Excessive ROS production causes oxidative damage to the lipid, protein and deoxyribonucleic acid (DNA) of a pathogen which eventually leads to cell death (Slauch, 2011). Despite the mechanisms used by the neutrophils and macrophages to combat the infection, $C$. albicans can survive in the host by expressing the antioxidative defense enzymes (Abegg et al., 2010). These enzymes play a crucial role in shielding the organism from numerous oxidative damages deployed by the host immune system (Hussain et al., 2015).

Infections initiated by $C$. albicans are becoming difficult to treat due to the emergence of strains that are resistant to antibiotics. The genetic alteration of this strain also enhances its virulency which creates another problem for the host to resolve the infections (Gow et al., 2011). The evolution of fungal resistance to the current 
available antibiotics has necessitated the research for more novel antimicrobial compounds.

Many local plants produce a diverse range of bioactive compounds; therefore, they are widely used in traditional medicine. Quercus infectoria (QI) gall is one of the herbaceous plants grouped under the family of Fagaceae. In Malaysia, the gall of QI is commonly known as "Manjakani" and it is widely used in traditional medicine. Recently, research in the pharmacological activities of QI gall extract, specifically on their antimicrobial activity has attracted numerous attentions. Previous study has documented that QI gall possesses numerous medicinal properties such as antimicrobial (Basri et al., 2005), antidiabetic, anti-inflammatory as well as antioxidant properties (Aivazi and Vijayan, 2009).

Previous research also has reported that QI gall extract has an antifungal activity against $C$. albicans (Baharuddin et al., 2015), however its mechanism in inhibiting or killing the microorganism is still unclear. Besides, the effect of the extract on gene expression of the antioxidative defense enzymes in $C$. albicans that encode superoxide dismutase (SOD), catalase (CAT) and glutathione peroxidase (GPX) is still yet to be explored. These enzymes which are fundamental protectors against all forms of stress play a crucial role in shielding the organism from numerous oxidative stresses deployed by the phagocytes to hinder the killing mechanism by a host, allowing pathogens to survive and finally induce disseminated infection. Therefore, the aim of this research was to determine the effect of QI gall extract on the expression of antioxidative defense enzymes in $C$. albicans. The present study demonstrated QI gall extract able to downregulate the antioxidative enzyme gene expression in $C$. albicans. Therefore, this elucidated mechanism associated with the organism's survival resilience represents a key target for the development of anti-Candida agents in future.

\section{MATERIALS AND METHODS}

\section{Plant material and preparation of QI gall extract}

Quercus infectoria (QI) galls were purchased from the local herbal shop in Kota Bharu, Kelantan and identified based on its physical appearances in which the shape was globose or rounded with rough surface, associated with 1.0 to $1.5 \mathrm{~cm}$ external diameter, greyish-brown to brownish-black in color and had a slight odor (Vanga et al., 2017). The galls were then washed with distilled water and left to dry at room temperature. Prior to extraction, the galls were crushed and ground to powder. Quercus infectoria gall aqueous extraction was performed according to the method described by Baharuddin et al. (2015). Aqueous extract of QI gall was prepared by immersing $100 \mathrm{~g}$ of gall powder into a sterile bottle containing $500 \mathrm{~mL}$ of sterile distilled water and placed in a $50{ }^{\circ} \mathrm{C}$ water bath for $72 \mathrm{~h}$. Then, the crude extract was filtered using Whatman filter paper No. 1 and concentrated under vacuum using a rotary evaporator (Heidolph, Germany). The resulting pellet was freeze- dried at $-50{ }^{\circ} \mathrm{C}$ under vacuum until a fine crystal-like crude extract was produced. The crude extract was stored in an airtight jar at $4{ }^{\circ} \mathrm{C}$ until future use.

\section{Fungal strains and preparation of a standardized inoculum}

Candida albicans American type culture collection (ATCC) 10231TM (Virginia, USA) was used in this study. The organism was maintained on Sabouraud dextrose agar (SDA) at $35{ }^{\circ} \mathrm{C}$ for $24 \mathrm{~h}$. For all assays, the standardized inoculum of $C$. albicans was prepared at 1.5 $\times 10^{6} \mathrm{CFU} / \mathrm{mL}$ by adjusting the suspension into 0.5 McFarland standard.

Determination of minimum inhibitory concentration (MIC) and minimum fungicidal concentration (MFC)

The MIC of QI gall aqueous extract against $C$. albicans was determined by using broth microdilution susceptibility test method as described by CLSI (2012). A 96-microtiter plate was used, and the assay was performed in triplicates. One hundred $\mu \mathrm{L}$ of stock extract at $64 \mathrm{mg} / \mathrm{mL}$ was serially diluted in $100 \mu \mathrm{L}$ sterile distilled water to produce 10 different extract concentrations ranging between $16 \mathrm{mg} / \mathrm{mL}$ and $0.03 \mathrm{mg} / \mathrm{mL}$. Then, $100 \mu \mathrm{L}$ of the prepared inoculum were pipetted into every well containing extract (final concentration of $7.5 \times 10^{5}$ $\mathrm{CFU} / \mathrm{mL}$ ). For the positive control, $100 \mu \mathrm{L}$ of the inoculum was used alone, while extract without inoculum served as negative control. The plate was then incubated at $35{ }^{\circ} \mathrm{C}$ for $24 \mathrm{~h}$. The MIC value was defined as the lowest concentration of extract in the well that showed no turbidity (clear broth) by visual inspection (Bajpai et al., 2012). Determination of MFC was done by subculturing the broth with no turbidity or visible growth onto SDA plates (Pfaller et al., 2004). The plates were incubated at $35{ }^{\circ} \mathrm{C}$ for $24 \mathrm{~h}$. The MFC was defined as the lowest concentration of extract that grew less than 8 colonies (99.9\% cell killing) on the plates.

\section{Time-kill kinetic assay}

Time-kill assay was conducted based on the method described by Klepser et al. (1998). The standardized inoculum was treated with Ql gall extract at concentrations of $0.5 \times \mathrm{MIC}, 1 \times \mathrm{MIC}, 2 \times \mathrm{MIC}$ and $4 \times \mathrm{MIC}$. Then, $1 \mathrm{~mL}$ of $C$. albicans suspension was added into 9 $\mathrm{mL}$ of extract containing RPMI 1640 medium. The inoculum treated with amphotericin $B(100 \mu \mathrm{g} / \mathrm{mL})$ served as positive control, while inoculum alone was used as negative control. All tubes were then incubated at $35{ }^{\circ} \mathrm{C}$. At predetermined time points $(0,2,4,6$, and $24 \mathrm{~h}), 0.1 \mathrm{~mL}$ aliquot was removed and subsequently diluted into 3 times dilution before plated onto the SDA. The colony forming unit (CFU) of the organisms was determined. The procedure was performed in triplicate (three independent experiments) and a graph of the $\log _{10} \mathrm{CFU} / \mathrm{mL}$ against time was plotted. 
Malays. J. Microbiol. Vol 17(3) 2021, pp. 286-293

DOI: http://dx.doi.org/10.21161/mjm.201008

\section{Analysis of total protein profile by SDS-PAGE}

The fungal inoculum was treated with QI gall extract at the fungistatic and fungicidal concentrations for $2 \mathrm{~h}$ at 35 ${ }^{\circ} \mathrm{C}$. The untreated inoculum served as a control. Extraction of protein was performed using Y-PER ${ }^{\mathrm{TM}}$ yeast protein extraction reagent (Thermo scientific, South Africa). The concentration of the harvested protein was determined by using NanoDrop ${ }^{\text {TM }} 1000$ spectrophotometer (Thermo scientific, South Africa). The extracted proteins $(18.6 \mathrm{mg} / \mathrm{mL})$ were subjected to SDSPAGE by using $4 \%(\mathrm{w} / \mathrm{v})$ stacking gel and $12.5 \%(\mathrm{w} / \mathrm{v})$ separating gel at condition of $100 \mathrm{~V}$ for $10 \mathrm{~min}$ and $150 \mathrm{~V}$ for $1 \mathrm{~h}$, respectively. The gel was then stained with Coomassie blue (R-250) staining solution $[0.3 \%(\mathrm{w} / \mathrm{v})$ coomassie brilliant blue R-250 in $45 \%(\mathrm{v} / \mathrm{v})$ methanol, $40 \%(\mathrm{v} / \mathrm{v})$ acetic acid] for $30 \mathrm{~min}$ and de-stained overnight on a horizontal shaker (Thomas Scientific, USA) at 80 rpm. The protein bands were analysed by PageRuler ${ }^{\mathrm{TM}}$ Plus Prestained Protein Ladder, 10 to $250 \mathrm{kDa}$ (Thermo Scientific, South Africa) as a molecular weight marker for SDS-PAGE.

\section{Analysis of gene expression by Real-Time PCR (RT- qPCR)}

The expression analysis of superoxide dismutase (SOD1), catalase (CAT1) and glutathione peroxidase (GPX3) genes from the extract-treated C. albicans was performed according to the method which was previously described by Hussain et al. (2015) and Khan et al. (2015). Candida albicans inoculum was treated with the extract at fungistatic and fungicidal concentrations for $2 \mathrm{~h}$. The untreated inoculum served as a negative control whereby the extract was replaced with distilled water. Total RNA from each sample were isolated using Qiagen RNeasy Mini Kit (Qiagen, Germany) according to the manufacturer's instruction. The RNA concentration was determined using NanoDrop ND-1000 spectrophotometer. cDNA synthesis was performed using ReverAid First Strand cDNA synthesis Kit (Thermo Scientific, South Africa) according to the manufacturer's protocol.

Primers for target genes were designed by using Primer3Plus software to identify a unique region that was suitable for amplification. For endogenous control, actin (ACT1) was used as a housekeeping gene. Real time quantification was performed by using PowerUp ${ }^{T M}$ SYBR $^{\text {TM }}$ Green Master Mix (Applied Biosystem. USA) according to the manufacturer's protocol with $20 \mu \mathrm{L}$ of the final volume. Instrument from Applied Biosystem 7500 Real-Time PCR System was used in this study. The primer sequences and annealing temperature used in this study are shown in Table 1. The experiment was performed in triplicate. Ct values of each target gene were used to calculate the gene expression ratio using $2^{-\Delta \Delta C T}$ (Livak method). Relative quantification was used to find the relative expression of the target genes in the untreated and treated $C$. albicans with reference to the housekeeping gene, ACT1, for normalization.
Table 1: List of primers for respective genes used in this study.

\begin{tabular}{|c|c|c|c|}
\hline \multirow[t]{2}{*}{ Gene } & \multicolumn{2}{|c|}{ Primer sequence $\left(5^{\prime} \rightarrow 3^{\prime}\right)$} & \multirow{2}{*}{$\begin{array}{c}\text { Annealing } \\
\text { temperature } \\
\left({ }^{\circ} \mathrm{C}\right)\end{array}$} \\
\hline & $\begin{array}{l}\text { Forward } \\
\text { primer }\end{array}$ & $\begin{array}{c}\text { Reverse } \\
\text { primer }\end{array}$ & \\
\hline \multirow[t]{4}{*}{ SOD1 } & GTC GCT GTT & GGA CCA & 60 \\
\hline & GTC AGA GGT & GCA GAA & \\
\hline & GA & GTA CAA & \\
\hline & & CCA & \\
\hline \multirow[t]{3}{*}{ CAT1 } & TTG GTC AAC & ACC ATA & 60 \\
\hline & ACG GTC CAT & AGC ACC & \\
\hline & $\mathrm{TG}$ & GGA ACC TT & \\
\hline \multirow[t]{4}{*}{ GPX3 } & CGC AAT TTT & AAA ACC & 60 \\
\hline & GGT GTC AGT & CAC TTC & \\
\hline & TTC C & ACC AGG & \\
\hline & & CT & \\
\hline \multirow[t]{4}{*}{ ACT1 } & GTT TTG GAT & TCA AGT & 60 \\
\hline & TCT GGT GAT & CTC TAC & \\
\hline & GGT GTT & CAG CCA & \\
\hline & & AAT CAA & \\
\hline
\end{tabular}

\section{Statistical analysis}

Data obtained were statistically analysed using IBM SPSS statistic 22. For determination of mean differences in antioxidative defense enzyme gene expression, the normality and homogeneity of variance were initially tested through the Shapiro-Wilk test. Then, one-way ANOVA with Tukey's HSD post hoc test was performed for statistical comparison between groups. The value of $p$ $<0.05$ was considered as statistically significant.

\section{RESULTS}

\section{Antifungal activity}

The MIC value of the aqueous QI gall extract against $C$. albicans was $8 \mathrm{mg} / \mathrm{mL}$, while the MFC value was 16 $\mathrm{mg} / \mathrm{mL}$. Results of the time-kill kinetic study are presented in Figure 1. After $2 \mathrm{~h}$ of treatment with extract at $0.5 \times \mathrm{MIC}$ ( $4 \mathrm{mg} / \mathrm{mL}$ ), the growth of $C$. albicans had declined initially, then it resumed but slower than the untreated cell growth after 4 to $24 \mathrm{~h}$. Meanwhile, continuous growth inhibition was observed when the cells were treated with extract at $1 \times$ MIC $(8 \mathrm{mg} / \mathrm{mL})$ compared to the growth control. After 6 h of extract treatment with $2 \times \operatorname{MIC}(16 \mathrm{mg} / \mathrm{mL})$ and $4 \times$ MIC $(32 \mathrm{mg} / \mathrm{mL})$, the viable cell count showed a decrease of $1 \log _{10} \mathrm{CFU} / \mathrm{mL}$ and more than $2 \log _{10} \mathrm{CFU} / \mathrm{mL}$ respectively. The fungicidal effect of the extract was seen at concentrations of $16 \mathrm{mg} / \mathrm{mL}$ and $32 \mathrm{mg} / \mathrm{mL}$ at $24 \mathrm{~h}$ of incubation (Figure 1). Therefore, the minimum fungistatic and fungicidal concentrations of extract was determined at $8 \mathrm{mg} / \mathrm{mL}$ and $16 \mathrm{mg} / \mathrm{mL}$ respectively. 


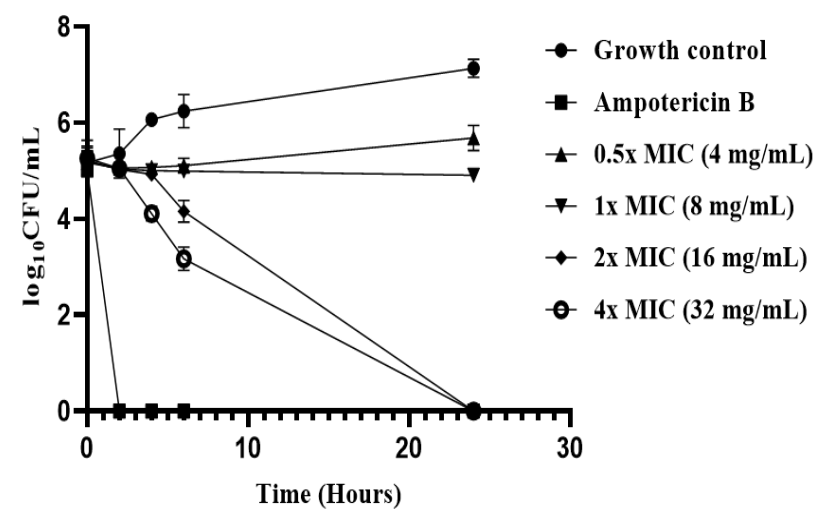

Figure 1: Time-kill kinetic assay of $C$. albicans treated with different concentrations of $\mathrm{Ql}$ gall extract. The experiment was performed in triplicate.

\section{Analysis of protein profile}

Protein band patterns in both untreated and extracttreated $C$. albicans were clearly separated and visualized in Figure 2. Overall, the protein band intensity of $C$. albicans treated with extract at $1 \times \mathrm{MIC}(8 \mathrm{mg} / \mathrm{mL})$ and $2 \times$ MIC $(16 \mathrm{mg} / \mathrm{mL})$ had reduced compared to the untreated cells when analysed qualitatively. The antioxidative defense proteins were estimated at $16.15 \mathrm{kDa}$ for SOD1 (Jones et al., 2004), 54.88 kDa for CAT1 (Wysong et al., 1998) and $19.85 \mathrm{kDa}$ for GPX3 (Cuomo et al., 2013).

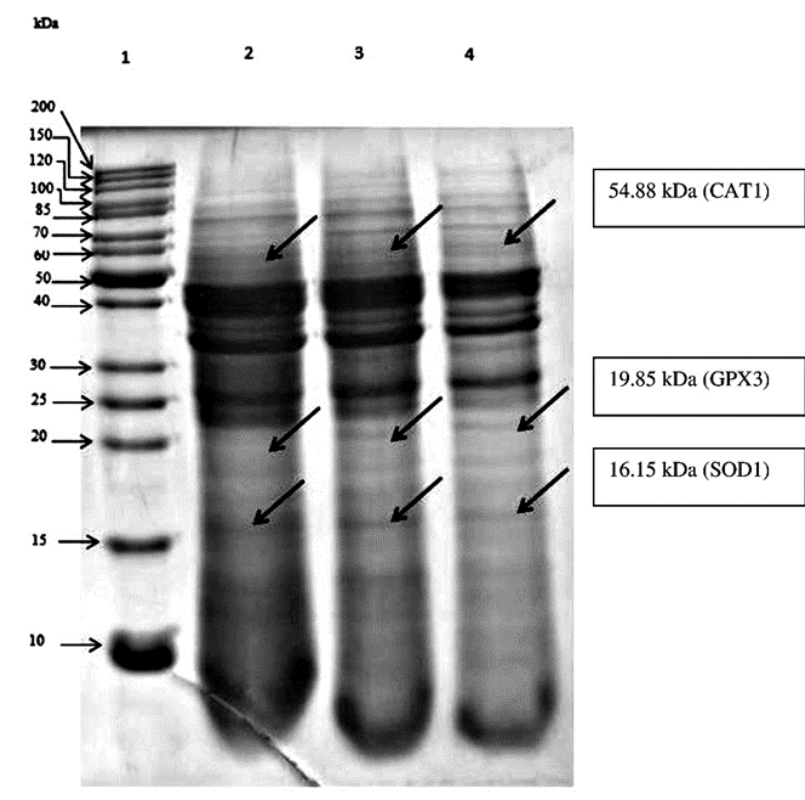

Figure 2: Zymography of cytoplasmic proteins analysed by SDS-PAGE following $2 \mathrm{~h}$ treatment of $C$. albicans with QI gall extract at $35^{\circ} \mathrm{C}$. Lane 1: protein ladder; Lane 2: untreated cells; Lane 3: extract-treated cells at $8 \mathrm{mg} / \mathrm{mL}$; Lane 4: extract-treated cells at $16 \mathrm{mg} / \mathrm{mL}$.

\section{Analysis of gene expression}

The effect of QI gall extract on the expression of SOD1, CAT1 and GPX3 genes, encoding superoxide dismutase, catalase and glutathione peroxidase respectively in $C$. albicans was investigated. The relative expression of the target genes in the treated and untreated samples was determined in reference to ACT1 as the internal control. The amplification efficiencies for SOD1, CAT1, GPX3 and ACT1 were $108 \%, 100 \%, 98 \%$ and $99 \%$ respectively (Supplementary Figure 1).

Figure 3 shows the relative expression of SOD1 in the treated and untreated cells. Based on the result obtained, there was no significant changes $(p=0.72)$ indicated in the relative expression of SOD1 after being treated with extract at $1 \times$ MIC $(8 \mathrm{mg} / \mathrm{mL})$. Meanwhile, treatment with extract at $2 \times$ MIC $(16 \mathrm{mg} / \mathrm{mL})$ for $2 \mathrm{~h}$ showed a slight decrease in the relative expression of SOD1 to 0.64 -fold compared to untreated cells which was not statistically significant $(p=0.14)$ to indicate the downregulation of SOD1 expression.

Treatment with both $1 \times$ MIC $(8 \mathrm{mg} / \mathrm{mL})$ and $2 \times \mathrm{MIC}$ $(16 \mathrm{mg} / \mathrm{mL})$ showed no significant changes in the relative expression of CAT1 after $2 \mathrm{~h}$ compared to the untreated cells (Figure 3 ). On the other hand, the relative expression of GPX3 was significantly reduced to 0.54 -fold $(p=0.04)$ and 0.4 -fold $(p=0.01)$ with $1 \times$ MIC and $2 \times$ MIC extract treatment respectively as compared to the untreated cells.

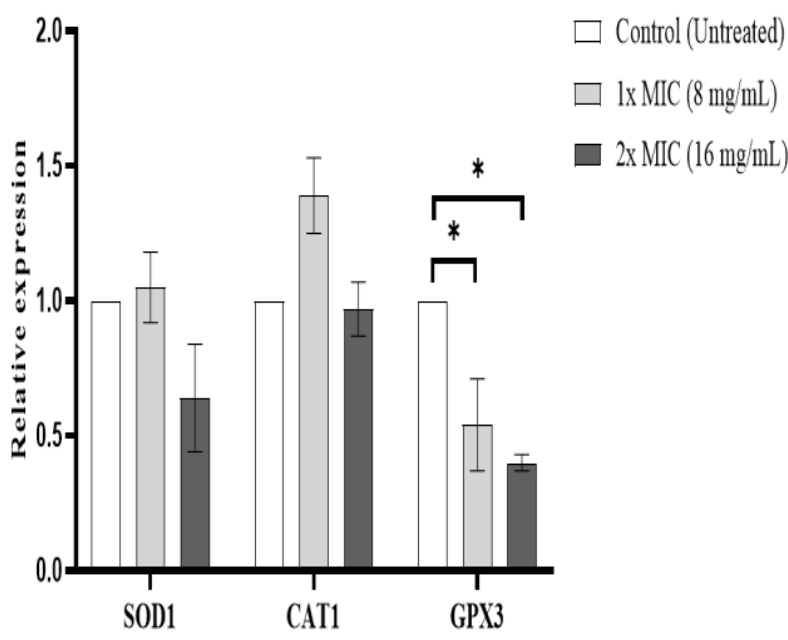

Figure 3: Relative expression of SOD1, CAT1 and GPX3 genes expression in QI gall extract-treated $C$. albicans. Asterisk $\left({ }^{*}\right)$ indicates a statistically significant difference $(p$ $<0.05$ ) between the test groups and negative control group (untreated). Comparison of the gene expression level between groups (untreated cells, treated cells with $1 \times \mathrm{MIC}$ and $2 \times \mathrm{MIC}$ ) was determined by one-way ANOVA, followed by Tukey post hoc test. 


\section{DISCUSSION}

The MIC and MFC values of QI gall extract against $C$. albicans in this study are slightly higher than the results from the previous study by Baharuddin et al. (2015) which reported the MIC value of $1 \mathrm{mg} / \mathrm{mL}$ and MFC of $4 \mathrm{mg} / \mathrm{mL}$ This possibly occurred due to some variations in the technical aspects which include environment conditions of the experiments and operator skills. The variation of the extract biological activities can also be due to different extraction method applied and its functional properties are largely contributed by the amount of bioactive compound in the extract (Quispe-Condori et al., 2008). Different source of plant used also might have contributed to this difference. According to Atanasov et al. (2015), chemical constituents contained inside the herbs are varied depending on the growing location and the environmental conditions. Factors such as ground and the soil where the plant was grown may contribute to this variation.

Based on time-kill kinetic study, the inhibitory effect of the extract can be observed even at the lowest concentration used $(4 \mathrm{mg} / \mathrm{mL})$ and it is apparently fungistatic at the concentration of $8 \mathrm{mg} / \mathrm{mL}$. This could be due to the interference on the protein production, cellular metabolism and DNA replication of the treated organism (Leela and Satirapipathkul, 2011). The fungistatic effect of antimicrobial helps the host immune defense to destroy the invading pathogen (Pfaller et al., 2004). Meanwhile, the fungicidal activity of an antimicrobial agent is defined as greater than $3 \log _{10}$-fold decrease in CFUs (surviving bacteria), which is equivalent to $99.9 \%$ killing of the inoculum at a point of time compared to at $0 \mathrm{hr}$ (Klepser et al., 1997). This study showed that the minimum extract concentration to kill $99.9 \%$ of $C$. albicans following $24 \mathrm{~h}$ of treatment was $16 \mathrm{mg} / \mathrm{mL}$. The fungicidal activity of extract was found to be less potent compared to the antifungal reference drug (amphotericin B at $100 \mu \mathrm{g} / \mathrm{mL}$ ) in which it completely killed the organisms after $2 \mathrm{~h}$ of treatment.

The killing activity of QI gall extract against $C$. albicans was found to be concentration dependent. Therefore, fungistatic and fungicidal concentrations of the extract were subsequently chosen in SDS-PAGE and RT-qPCR analysis in order to further analyse its effect on organism's protein profile and gene expression. This study showed that the protein production of $C$. albicans was affected after being exposed to the extract at fungistatic and fungicidal concentrations for $2 \mathrm{~h}$ (Figure 2 ). The growth inhibition is possibly due to the loss of protein function, leading to interference of normal cellular process. The suppression of the organism's protein synthesis could be one of the mechanisms of the antimicrobial killing effect. However, a more specific test like Western blot or flowcytometry analysis is necessary to confirm the expression of specific proteins.

RT-qPCR is another method of choice in the detection of mRNA as it allows a sensitive and specific quantitation of nucleic acids (Ponchel et al., 2003). Relative quantification method was used in this study to describe the relative expression of the target genes between untreated and treated $C$. albicans. Target genes selected for this study were SOD1, CAT1 and GPX3 to encode antioxidative defense enzymes present in $C$. albicans as these enzymes are among important virulence factors in the organism for establishment of systemic model of infections (Abegg et al., 2010). In a human body, the immune system plays a pivotal role in surveillance as well as elimination of any fungal invasion by releasing a set of chemicals which is known as reactive oxygen species (ROS). The chemical released is extremely toxic which can cause significant damage to the pathogen (GonzálezPárraga et al., 2003). However, the presence of these enzymes protects $C$. albicans from the killing effect of ROS by catalysing the conversion ROS into a less harmful chemical thus ensuring its survival (Dantas et al., 2015). Survivability of pathogen inside the body has a potential to create more dangerous infection.

SOD1 plays a crucial role in protecting pathogen from oxidative stress induced by immune cells. This enzyme catalysed the conversion of superoxide anions released by macrophage into less harmful molecule of hydrogen peroxide $\left(\mathrm{H}_{2} \mathrm{O}_{2}\right)$ and oxygen $\left(\mathrm{O}_{2}\right)$. SODs are required for $C$. albicans to resist the macrophage-mediated killing induced following phagocytosis (Hwang et al., 2017). CAT1 is also one of the crucial antioxidative defense enzymes in $C$. albicans. This enzyme is consistently ready to neutralize $\mathrm{ROS}$ encountered extracellularly. CAT1 spontaneously converts hydrogen peroxide $\left(\mathrm{H}_{2} \mathrm{O}_{2}\right)$ into oxygen $\left(\mathrm{O}_{2}\right)$ and water $\left(\mathrm{H}_{2} \mathrm{O}\right)$. GPX3 is an essential enzyme in detoxification of hydrogen peroxide to overcome the harmful effect to pathogen (Miramón et al., 2014).

The amplification efficiencies of the target genes in this study were $108 \%$ for SOD $1,100 \%$ for CAT $1,98 \%$ for GPX3 and 99\% for ACT1. The ideal level of amplification efficiency must be in between $95 \%$ to $110 \%$ to ensure the results obtained are reliable (Bustin et al., 2004). Therefore, the quantification of the mRNA state levels present in the untreated and treated samples in this study are reliable to be quantified and analysed. Based on the results obtained, a significant downregulation of GPX3 gene $(p<0.05)$ which encoded for GPX enzyme in $C$. albicans suggested that suppression of GPX3 gene expression could be one of the fungicidal mechanisms of QI gall extract against $C$. albicans.

Meanwhile, the fungistatic and fungicidal concentrations of the extract did not significantly reduce the gene expression of SOD1 and CAT1. However, a reduction trend in the relative gene expression SOD1 and CAT1 was observed when the cells were treated with extract at fungicidal concentration $(16 \mathrm{mg} / \mathrm{mL})$ compared to the untreated cells (Figure 3 ). It is possible that the level of active compound present in the extract at the tested concentration was not sufficiently high to affect the expression of the target genes. According to the Siqueira et al. (2012), the presence of sufficient phytochemical compounds is essential for an optimum effect of plant extract. In addition, treatment time is also one of plausible factors that may affect the study results. As such, a significant reduction in the SOD1 and CAT1 genes 
expression might be observed if the incubation time is increased.

In a previous study, aqueous QI gall extract had significantly downregulated a catalase gene expression in the methicillin resistant Staphylococcus aureus (Khairon et al., 2016). Besides that, its protein expression was also reduced. These findings suggest the potential of QI gall extract to interrupt the antioxidative defense system in other pathogens. Meanwhile, another study conducted by Khan et al. (2015) found that treatment with monoterpene phenol compound had compromised the antioxidative defense system by affecting the regulatory functions of several antioxidative defense enzymes (SOD, catalase, GPX, glutathione S-transferase and glutathione reductase) in $C$. albicans. Toxic oxidizing effects of this compound on the antioxidative defense system had consequently weakened its function in protecting the organism against the damaging effect of ROS generated by the immune cells.

Based on Baharuddin et al. (2015), phenol is among of major phytochemical compounds contained in the aqueous QI gall extract. The inhibition of the GPX3 in the present study might be due to the action of phenol presents in the extract. According to Ultee et al. (2002), hydroxyl groups and alpha, beta-double bonds in the phenolic compound play an important role in the antimicrobial activity. Thus, further investigations involving isolation and identification of the active phytochemical components responsible for the observed effects are required and we believe that it may open the door for further studies on its use in therapy of fungal infections.

\section{CONCLUSION}

In conclusion, our data suggests that QI gall extract could exert its immunomodulatory activity via modulation of the fungal antioxidative defense enzyme expressions and may have the potential in inducing the oxidative killing effect on $C$. albicans. Of note, the present findings elucidated a preliminary mechanism associated with the organism's survival resilience which represents a key target for the development of anti-Candida agents in future.

\section{ACKNOWLEDGEMENTS}

Authors would like to express a sincere gratitude to Universiti Sains Malaysia RUI grant (No: 1001/PPSK/812163) for the fund provided for this research. A special thanks also to Mrs Siti Kurunisa Mohd Hanafiah from Biomedicine Program, School of Health Sciences and Mr Badrul Syam Mat Zainuddin from Institute for Research in Molecular Medicine (INFORMM) Health Campus for all technical assistance.

\section{REFERENCES}

Abegg, M. A., Alabarse, P. V. G., Casanova, A., Hoscheid, J., Salomon, T. B., Hackenhaar, F. S. and Benfato, M. S. (2010). Response to oxidative stress in eight pathogenic yeast species of the genus Candida. Mycopathologia 170, 11-20.

Aivazi, A. A. and Vijayan, V. A. (2009). Larvacidal activity of oak Quercus infectoria Oliv. Fagaceae gall extracts against Anopheles stephensi Liston. Parasitology Research 104, 1289-1293.

Atanasov, A. G., Waltenberger, B., Pferschy-Wenzig, E.-M., Linder, T., Wawrosch, C., Uhrin, P. and Stuppner, H. (2015). Discovery and resupply of pharmacologically active plant-derived natural products: A review. Biotechnology Advances 33, 15821614.

Baharuddin, N. S., Abdullah, H. and Abdul Wahab, W. A. (2015). Anti-Candida activity of Quercus Infectoria gall extracts against Candida species. Journal of Pharmacy and Bioallied Sciences 7, 15-20.

Bajpai, V. K., Baek, K. and Kang, S. C. (2012). Inhibitory effects of sugiol, a biologically active abietane type diterpenoid from Metasequoia glyptostroboides. Romanian Biotechnological Letters 17, 7288.

Basri, D. F., Ha, F. S., Zin, N. M. and Jantan, I. (2005). Antibacterial activity of the galls of Quercus infectoria. Malaysian Journal of Science 24, 257-262.

Bustin, S. A., Benes, V., Nolan, T. and Pfaffl, M. W. (2004). Quantitative Real-Time RT-PCR - A Perspective. Journal of Molecular Endocrinology 34, 597-601.

Chin, V. K., Lee, T. Y., Rusliza, B. and Chong, P. P. (2016). Dissecting Candida albicans infection from the perspective of $C$. albicans virulence and omics approaches on host-pathogen interaction: A review. International Journal of Molecular Sciences 17.

CLSI, Clinical and Laboratory Standards Institute. (2012). Reference method for broth dilution antifungal susceptibility testing of yeasts; $4^{\text {th }}$ Informational Supplement. CLSI document M27-S4. Clinical and Laboratory Standards Institute, Wayne, PA.

Cuomo, C., Bennett, R., Hirakawa, M., Noverr, M., Mitchell, A., Young, S. K. et al. (2013). The genome sequence of Candida albicans SC5314. National Center for Biotechnology Information (NCBI): https://www.ncbi.nlm.nih.gov/protein/KHC89529.1 [Retrieved on 13 March 2017].

Dantas, A., Da, S., Day, A., Ikeh, M., Kos, I., Achan, B. and Quinn, J. (2015). Oxidative stress responses in the human fungal pathogen, Candida albicans. Biomolecules 5, 142-165.

González-Párraga, P., Hernández, J. A. and Argüelles, J. C. (2003). Role of antioxidant enzymatic defences against oxidative stress $\left(\mathrm{H}_{2} \mathrm{O}_{2}\right)$ and the acquisition of oxidative tolerance in Candida albicans. Yeast 14, 1161-1169.

Gow, N. A. R., Veerdonk, F. L. Van De, Brown, A. J. P., and Netea, M. G. (2011). Candida albicans morphogenesis and host defence: Discriminating invasion from colonization. Nature 10, 112-122.

Hawkshead, J. J., Van Dyke, R. B., Hassig, S. E., Webber, L. S. and Begue, R. E. (2016). Speciesbased comparison of disease severity and risk factors for disseminated Candida infections in pediatric 
patients. Infection and Drug Resistance 9, 59-70.

Hussain, R. M., Khalid, A. H. F., Mustakim, M. and Suhaimi, H. (2015). Upregulation of $\operatorname{Tr} x B$ expression by Piper Betel Linn ethanolic extract suggests induction of oxidative stress which potentially contributes to killing of Staphylococcus aureus in vitro. International Journal of Pharmacy and Pharmaceutical Sciences 7(2), 154-159.

Hwang, C., Rhie, G., Oh, J. and Huh, W. (2017). Copper and zinc-containing superoxide dismutase $(\mathrm{Cu} / \mathrm{ZnSod})$ is required for the protection of Candida albicans against oxidative stresses and the expression of its full. Microbiology 3705-3713.

Jones, T., Federspiel, N. A., Chibana, H., Dungan, J., Kalman, S., Magee, B. B., Newport, G., Thorstenson, Y. R., Agabian, N., Magee, P. T., Davis, R. W. and Scherer, S. (2004). The diploid genome sequence of Candida albicans. Proceedings of the National Academy of Sciences 101(19), 73297334.

Khairon, R., Zin, N. M., Rahman, M. A., and Basri, D. F. (2016). Comparative proteomic analysis of differential proteins in response to aqueous extract of Quercus infectoria gall in methicillin-resistant Staphylococcus aureus. International Journal of Proteomics 2016, 9.

Khan, A., Ahmad, A., Ahmad Khan, L., Padoa, C. J., van Vuuren, S. and Manzoor, N. (2015). Effect of two monoterpene phenols on antioxidant defense system in Candida albicans. Microbial Pathogenesis 80, 5056.

Klepser, M. E., Ernst, E. J., Lewis, R. E., Ernst, M. E., and Pfaller, M. A. (1998). Influence of test conditions on antifungal time-kill curve results: Proposal for standardized methods. Antimicrobial Agents and Chemotherapy 42, 1207-1212.

Klepser, M. E., Wolfe, E. J., Jones, R. N., Nightingale, C. H. and Pfaller, M. A. (1997). Antifungal pharmacodynamic characteristics of fluconazole and amphotericin B tested against Candida albicans. Antimicrobial Agents and Chemotherapy 41, 13921395.

Leela, T. and Satirapipathkul, C. (2011). Studies on the antibacterial activity of Quercus infectoria galls. In: IACSIT Press Singapore. International Conference on Bioscience, Biochemistry and Bioinformatics. Singapore 5, 410-414.

Miramón, P., Dunker, C., Kasper, L., Jacobsen, I. D., Barz, D., Kurzai, O. and Hube, B. (2014). A family of glutathione peroxidases contributes to oxidative stress resistance in Candida albicans. Medical Mycology 52 , 223-239.

Pfaller, M. A., Sheehan, D. J. and Rex, J. H. (2004). Determination of fungicidal activities against yeasts and molds: Lessons Learned from bactericidal testing and the need for standardization. Clinical Microbiology Review 17, 2, 268-280.

Ponchel, F., Toomes, C., Bransfield, K., Leong, F. T., Douglas, S. H., Field, S. L., Bell, S. M., Combaret, V., Puisieux, A., Minghell, A. J., Robinson, P. A., Inglehearn, C. F., Isaacs, J. D. and Markham, A. F.
(2003). Real-time PCR based on SYBR-Green I fluorescence: An alternative to the taqman assay for a relative quantification of gene rearrangements, gene amplifications and micro gene deletions TCR-alpha. BMC Biotechnology 3(18).

Quispe-Condori, S., Foglio, M. A., Paulo T. V., Rosaa. P. T. and Meireles, M. A. (2008). Obtaining $\beta$ caryophyllene from Cordia verbenacea de Candolle by super crtitical fluid extraction. The Journal of Supercritical Fluids 46, 27-32.

Sardi, J. C. O., Scorzoni, L., Bernardi, T., FuscoAlmeida, A. M. and Mendes-Giannini, M. J. S. (2013). Candida species: Current epidemiology, pathogenicity, biofilm formation, natural antifungal products and new therapeutic options. Journal of Medical Microbiology 62, 10-24.

Silva, S., Negri, M., Henriques, M., Oliveira, R., Williams, D. W. and Azeredo, J. (2012). Candida glabrata, Candida parapsilosis and Candida tropicalis: Biology, epidemiology, pathogenicity and antifungal resistance. FEMS Microbiology Reviews 36, 288-305.

Singh, A., Verma, R., Murari, A. and Agrawal, A. (2014). Oral candidiasis: An overview. Journal of Oral and Maxillofacial Pathology 18, 81-85.

Siqueira, C. F. Q., Cabral, D. L. V., Sobrinho, T. J. S. P., Amorim, E. L. C., Melo, J. G., Araújo, T. A. S. and Albuquerque, U. P. (2012). Levels of tannins and flavonoids in medicinal plants: Evaluating bioprospecting strategies. Evidence-Based Complementary and Alternative Medicine 2012, 7.

Slauch, J. M. (2011). How does the oxidative burst of macrophages kill bacteria? Still an open question. Molecular Microbiology 80, 580-583.

Tzar, M. N. K., Suhaila, B., Shamsul, A. S. and Azizah, M. (2013). Epidemiology of fungal infections at an infectious disease reference centre in Malaysia. International Medical Journal Malaysia 12, 3942.

Ultee, A., Bennik, M. H., and Moezelaar, R. (2002). The phenolic hydroxyl group of carvacrol is essential for action against the food-borne pathogen Bacillus cereus. Applied and Environmental Microbiology 68, 1561-1568.

Vanga, S., Pingili, M. and Tharigoppula, S. (2017). Phytochemical screening and evaluation of antifungal activity of gall extracts of Quercus infectoria. International Journal of Pharmaceutical Science and Research 8(7), 3010-3013.

Weiss, J., Kao, L., Victor, M., Elsbach, P., and Victor, M. (1985). Oxygen-independent intracellular and oxygen-dependent extracellular killing of Escherichia coli $\mathrm{S} 15$ by human polymorphonuclear leukocytes. Journal of Clinical Investigation 76, 206-212.

Wysong, D. R., Christin, L., Sugar, A. M., Robbins, P. W. and Diamond, R. D. (1998). Cloning and sequencing of a Candida albicans catalase gene and effects of disruption of this gene. Infection and Immunity 66(5), 1953-1961. 
Malays. J. Microbiol. Vol 17(3) 2021, pp. 286-293

DOI: http://dx.doi.org/10.21161/mjm.201008

\section{SUPPLEMENTARY INFORMATION}

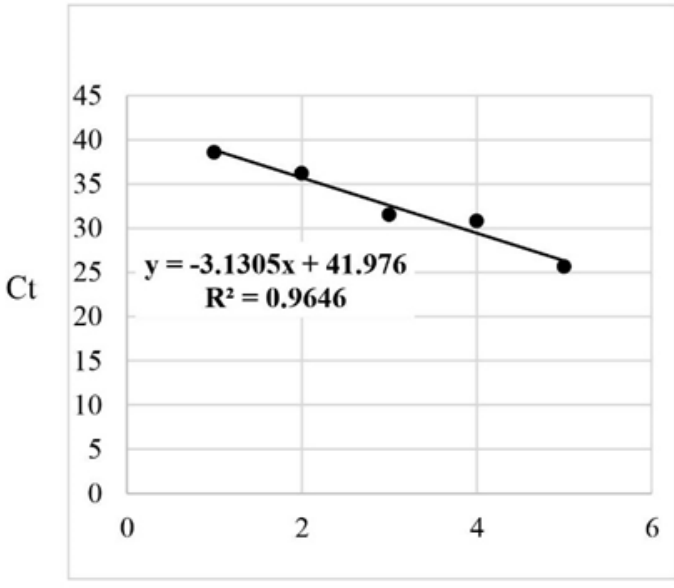

Log cDNA

(A)

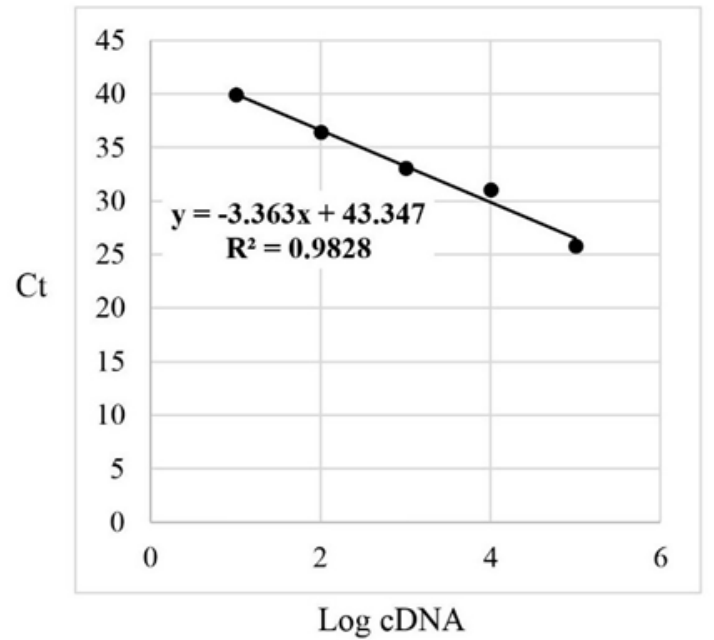

(C)

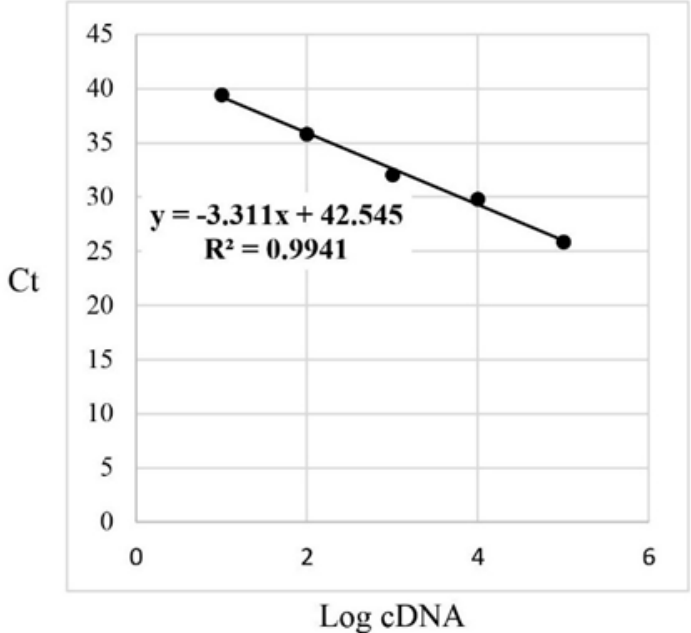

(B)

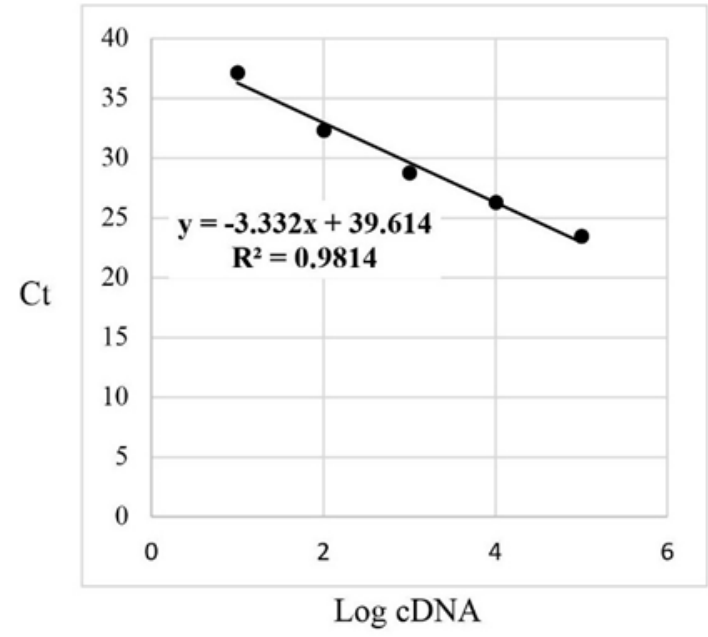

(D)

Supplementary Figure 1: Standard curve for target genes. A, SOD1; B, CAT1; C, GPX3; D, ACT1. Amplification efficiencies for SOD1, CAT1, GPX3 and ACT1 were 108\%, 100\%, 98\% and 99\% respectively. 